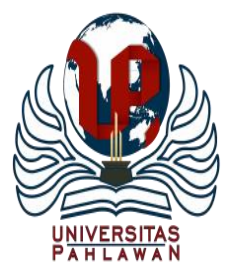

Edukatif : Jurnal Ilmu Pendidikan Volume 3 Nomor 5 Tahun 2021 Halm 1942 - 1956

EDUKATIF: JURNAL ILMU PENDIDIKAN

Research \& Learning in Education

https://edukatif.org/index.php/edukatif/index

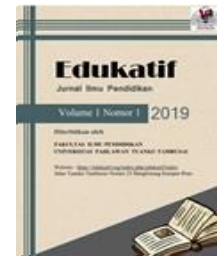

\title{
Challenge Based Learning Dalam Meningkatkan Kemampuan Berpikir Kreatif Siswa Pada Materi Persamaan Linear Satu Variabel
}

\author{
Fairazatunnisa $^{1 凶}$, Gelar Dwirahayu $^{2}$, Eva Musyrifah ${ }^{3}$ \\ Program Studi Pendidikan MIPA, Universitas Indraprasta PGRI Jakarta, Indonesia ${ }^{1}$ \\ Program Studi Pendidikan Matematika, UIN Syarif Hidayatullah Jakarta, Indonesia2,3

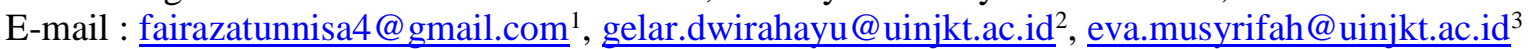

\begin{abstract}
Abstrak
Penelitian ini bertujuan untuk menganalisis pengaruh model pembelajaran Challenge Based Learning terhadap kemampuan berpikir kreatif matematis siswa. Indikator kemampuan berpikir kreatif matematis yang diukur dalam penelitian ini terdiri dari: (a) memperinci, (b) kelancaran, dan (c) keluwesan. Metode yang digunakan adalah quasi eksperimen dengan desain randomized control group posttest only. Pengambilan sampel menggunakan teknik cluster random sampling. Penelitian ini dilaksanakan di SMP Negeri 169 Jakarta dengan siswa kelas VII A sebagai kelas eksperimen yaitu pembelajaran dengan Challenge Based Learning dan kelas VII E sebagai kelas kontrol yaitu pembelajaran dengan konvensional. Data dianalisis dengan menggunakan Uji-t untuk menunjukkan perbedaan kemampuan siswa kelas eksperimen dan kelas kontrol. Berdasarkan analisis data, pada taraf nyata $5 \%$ diperoleh nilai sig $=0,002<\alpha=0,05$, dengan kata lain kemampuan berpikir kreatif matematis siswa pembelajarannya menggunakan Challenge Based Learning lebih tinggi dibandingkan dengan kemampuan berpikir kreatif matematis siswa yang pembelajarannya konvensional. Secara spesifik, indikator dari kemampuan berpikir kreatif matematis yang mendapatkan hasil paling tinggi yaitu indikator elaborasi.
\end{abstract}

Kata Kunci: Challenge Based Learning, Berpikir Kreatif Matematis, persamaan linear.

\begin{abstract}
This study aims to analyze the effect of the Challenge Based Learning learning model on students mathematical creative thinking skills. The indicators of mathematical creative thinking skills measured in the research consist of: (a) elaboration, (b) fluency, and (c) flexibility. The method used is a quasi-experimental design with a randomized control group posttest only. Sampling using cluster random sampling technique. This research was conducted in SMP Negeri 169 Jakarta with students of class VII A as the experimental class, namely learning with Challenge Based Learning and class VII E as the control class, namely learning with conventional methods. The data were analyzed using t-test to show differences in the abilities of the experimental class and control class students. Based on data analysis, at 5\% significance level, sig $=0,002<\alpha$ $=0,05$, In other words, students' mathematical creative thinking skills using Challenge Based Learning are higher than the students' mathematical creative thinking skills using conventional learning. Specifically, the result shows that mathematical reflective thinking skills highest score on the indicator of elaboration.
\end{abstract}

Keywords: Challenge Based Learning, Mathematical Creative Thinking, Linear Equation.

Copyright (c) 2021 Fairazatunnisa, Gelar Dwirahayu, Eva Musyrifah

$\square$ Corresponding author

Email : fairazatunnisa4@gmail.com

DOI : https://doi.org/10.31004/edukatif.v3i5.702

ISSN 2656-8063 (Media Cetak)

ISSN 2656-8071 (Media Online)

Edukatif : Jurnal Ilmu Pendidikan Vol 3 No 5 Tahun 2021 p-ISSN 2656-8063 e-ISSN 2656-8071 
1943 Challenge Based Learning Dalam Meningkatkan Kemampuan Berpikir Kreatif Siswa Pada Materi Persamaan Linear Satu Variabel - Fairazatunnisa, Gelar Dwirahayu, Eva Musyrifah

DOI: https://doi.org/10.31004/edukatif.v3i5.702

\section{PENDAHULUAN}

Keterampilan berpikir kreatif merupakan salah satu hal penting yang harus dimiliki oleh setiap orang dalam menghadapi era globalisasi yang penuh tantangan dan persaingan. Dengan kreativitasnya, seseorang dapat mewujudkan dirinya melalui berbagai karya, baik berupa gagasan, ide, maupun suatu produk. Seseorang yang memiliki kemampuan berpikir kreatif akan menjadi pribadi yang unggul di kehidupannya, tidak hanya dalam pembelajaran tetapi juga dalam bermasyarakat. Kemampuan berpikir kreatif inilah sebagai alat yang memungkinkan manusia meningkatkan kualitas hidupnya terutama pada era pembangunan seperti sekarang ini, kesejahteraan masyarakat dan negara kita bergantung pada sumbangan kreatif, baik berupa ide-ide baru, penemuan-penemuan baru, dan teknologi baru dari masyarakatnya. Berpikir kreatif dalam matematika tentu berbeda pemaknaannya dengan bidang lain seperti seni dan sastra. Saat ini kemampuan berpikir kreatif telah menjadi salah satu fokus pembelajaran yang penting untuk dikembangkan dalam matematika. Dalam pembelajaran matematika siswa sering kali mengalami kesulitan dalam menyelesaikan soal yang rumit atau permasalahan yang tidak rutin. Maka dari itu, kemampuan berpikir kreatif sangat dibutuhkan untuk melatih siswa dalam menyelesaikan soal-soal yang rumit tersebut. Seorang siswa yang memiliki kemampuan berpikir kreatif selalu mempunyai rasa ingin tahu, ingin mencoba-coba, memunculkan suatu ide gagasan baru dalam memecahkan masalah matematika. Dengan demikian, kemampuan berpikir kreatif matematis sangat dibutuhkan oleh setiap siswa, demi mewujudkan prestasi belajar matematika siswa yang lebih baik.

Dewasa ini, pembelajaran matematika yang di sekolah diarahkan pada kemampuan berpikir tingkat tinggi. Menurut Stein kemampuan berpikir tingkat tinggi yaitu menggunakan pemikiran yang kompleks, non algorithmic untuk menyelesaikan suatu tugas, ada yang tidak dapat diprediksi, menggunakan pendekatan yang berbeda dengan tugas yang telah ada dan berbeda dengan contoh (Purbaningrum, 2017). Dalam penelitian ini, peneliti mengkaji tentang kemampuan berpikir kreatif matematis siswa. Kemampuan berpikir kreatif seseorang tidak hanya ditentukan pada banyaknya jawaban yang diberikan, tetapi disesuaikan dengan masalah yang dihadapi. Berpikir kreatif merupakan suatu kebiasaan dari pikiran yang dilatih dengan memperhatikan intuisi, menghidupkan imajinasi, mengungkapkan kemungkinan-kemungkinan baru, membuat sudut pandang yang menakjubkan dan membangkitkan ide-ide yang tidak terduga (Purwaningrum, 2016). Kreativitas dalam matematika lebih pada kemampuan berpikir kreatif karena secara umum sebagian besar aktivitas yang dilakukan seseorang yang belajar matematika adalah berpikir. Sing mendefinisikan kreativitas matematis sebagai proses merumuskan hipotesis yang mengenai penyebab dan pengaruh dalam situasi matematis, pengujian, pengujian kembali hipotesis, membuat modifikasi dan akhirnya mengkomunikasikan hasil (Nova et al., 2012). Kreativitas didefinisikan sebagai kemampuan siswa untuk memecahkan masalah matematika tidak hanya dengan mengingat rumus atau meniru algoritma pemecahan masalah sebelumnya tetapi memecahkan masalah matematika menggunakan metode atau prosedur berpikir yang tidak biasa sehingga kebaruannya dapat dilihat. Plausibility didefinisikan sebagai kemampuan siswa untuk memberikan jawaban yang logis, benar, dan plausibility argumen untuk solusi masalah matematika. Plausibility bukanlah kemampuan untuk memberikan argumen dengan menebak-nebak karena jawaban tebakan akan sulit dibenarkan. Plausibility akan muncul di argumen logis yang disajikan siswa ketika siswa memberikan solusi untuk masalah yang diberikan. Plausibility didefinisikan sebagai kemampuan siswa untuk memecahkan masalah matematika yang menunjukkan konsep dasar matematika dengan jelas. Siswa tidak memberikan jawaban yang mengandung perasaan (Dwirahayu et al., 2021).

Beberapa metode dan strategi mungkin telah dilakukan oleh guru dalam proses pembelajaran untuk memberikan penguatan positif kepada siswa dengan memberikan berbagai alat peraga, dan menampilkan informasi yang sangat penting. Membuat tindakan positif merupakan faktor penting dalam merangsang fungsi otak yang dapat menunjukkan dan menciptakan kebaikan gaya belajar. Dengan menggunakan metode atau strategi yang tepat berarti guru dalam pembelajaran lebih menghemat tenaga, waktu dan meningkatkan 
prestasi belajar siswa. Meski tidak mudah untuk dijalankan, tapi dengan keyakinan, motivasi dan kemampuan yang dimilikinya, guru yang kreatif dapat mengembangkan dan menerapkan berbagai metode atau strategi pembelajaran dengan memperhatikan karakteristik siswa. Masalah matematika yang dihadapi siswa seringkali tidak segera dapat dicarikan pemecahannya, sedangkan siswa diharapkan dan dituntut untuk dapat menyelesaikan masalah tersebut. Siswa seolah-olah hanya mendengarkan, menyalin atau meniru apa yang ada diberikan oleh guru. Siswa tidak diperbolehkan atau didorong untuk mengembangkan potensi, dan kreativitasnya. Karena itu, ia perlu memiliki keterampilan untuk berpikir bahwa siswanya dapat menemukan cara yang tepat untuk memecahkan masalahnya. Kebiasaan dari menjiplak atau meniru pekerjaan orang lain membuat siswa menjadi orang yang hanya menggunakan. Kebiasaan siswa tersebut untuk mempelajari konsep secara hafalan tanpa pemahaman yang mendalam, dan siswa tidak mampu menerapkannya. Hal seperti ini membuat siswa kurang mampu berpikir kreatif dan tidak terlatih untuk melakukan analisis sebelum mengambil keputusan (Lince, 2016). Pembelajaran yang melibatkan keaktifan, kreativitas, kecakapan, hasil belajar, dan kemampuan berpikir kreatif siswa sesuai dengan sistem pendidikan nasional, hingga kini masih mengalami perkembangan, berbagai upaya pemerintah dilakukan untuk mengatasi permasalahan pendidikan seperti rendahnya keaktifan, kecakapan, kreativitas, hasil belajar, dan kemampuan berpikir kreatif yang dilatarbelakangi oleh pembelajaran yang bersifat konvensional dan teacher centered. Berpikir kreatif menuntut seorang anak untuk memiliki kemampuan dalam memecahkan masalah, mempunyai variasi jawaban, memiliki kemampuan menguasai suatu konsep permasalahan, menyampaikan ide atau gagasan suatu topik permasalahan. Oleh sebab itu, berpikir kreatif menjadi salah satu kemampuan yang dikembangkan dalam Kurikulum 2013, sehingga berpikir kreatif sangat berpengaruh terhadap hasil belajar di mana hasil belajar biasanya dipengaruhi pemahaman siswa terhadap suatu konsep pembelajaran serta kemampuan siswa untuk memecahkan suatu permasalahan dalam proses pembelajaran (Nugrahaeni et al., 2017).

Jauh sebelumnya National Council of Teachers of Mathematics memberikan standar bahwa dalam rangka mempersiapkan abad ke-21, siswa saat ini harus membekali diri mereka dengan kemampuan pemecahan masalah, kemampuan berkomunikasi, dan dengan kemampuan berpikir matematis dan kecenderungan matematika (mathematical propensity). Hal ini juga menyatakan bahwa siswa harus diberikan masalah yang menantang yang dapat merangsang siswa untuk mengembangkan cara-cara yang beragam dan berpikir kreatif. Kemampuan berpikir kreatif merupakan kemampuan yang berhubungan dengan kreativitas yang dapat diartikan sebagai cara berpikir untuk mengubah atau mengembangkan suatu permasalahan, melihat situasi atau permasalahan dari sisi yang berbeda, terbuka pada berbagai ide dan gagasan bahkan yang tidak umum (Meika \& Sujana, 2017). Representasi matematis dapat direpresentasikan menjadi representasi visual dan non visual. Visual representasi meliputi grafik, tabel, sketsa atau gambar, dan diagram; representasi non visual termasuk representasi numerik, dan persamaan matematika atau model matematika. Kekuatan representasi dapat terlihat jelas setiap kali representasi visual dan numerik digunakan dalam masalah rasio, proporsi, dan persen. Fokus penelitian pada representasi matematis non visual (Minarni et al., 2016). Saat ini kemampuan berpikir kreatif telah menjadi salah satu fokus pembelajaran yang penting untuk dikembangkan dalam matematika. Dalam pembelajaran matematika siswa sering mengalami kesulitan dalam menyelesaikan soal yang rumit atau permasalahan yang tidak rutin. Oleh karena itu, kemampuan berpikir kreatif sangat dibutuhkan untuk melatih siswa dalam menyelesaikan soal-soal yang rumit tersebut. Seorang siswa yang memiliki kemampuan berpikir kreatif selalu mempunyai rasa ingin tahu, ingin mencoba-coba, memunculkan suatu ide gagasan baru dalam memecahkan masalah matematika. Dengan demikian, kemampuan berpikir kreatif matematis sangat dibutuhkan oleh setiap siswa, demi mewujudkan prestasi belajar matematika siswa yang lebih baik. Wilson memberikan ciri-ciri kemampuan berpikir kreatif sebagai berikut: (1) Kelancaran (Fluency) yaitu kemampuan untuk membangkitkan sebuah ide sehingga terjadi peningkatan solusi atau hasil karya, (2) Fleksibelitas (Flexibility) yaitu kemampuan untuk memproduksi atau mengasilkan suatu produk, persepsi, atau ide yang bervariasi terhadap masalah, (3) Elaborasi (Elaboration) yaitu kemampuan untuk 
mengembangkan atau menumbuhkan suatu ide atau hasil karya, (4) Orisinalitas (Originality) yaitu kemampuan menciptakan ide-ide, hasil karya yang berbeda atau betul-betul baru, (5) Kompleksitas (Complexity) yaitu kemampuan memasukkan suatu konsep, ide, atau hasil karya yang sulit, ruwet, berlapislapis atau berlipat ganda ditinjau dari berbagai segi, (6) Keberanian mengambil resiko (Risk-taking) yaitu kemampuan bertekad dalam mencoba sesuatu yang penuh resiko, (7) Imajinasi (Imagination) yaitu kemampuan untuk berimajinasi, menghayal, menciptakan barang-barang baru melalui percobaan yang dapat menghasilkan produk sederhana, dan (8) Rasa ingin tahu (Curiosity) yaitu kemampuan mencari, meneliti, mendalami, dan keinginan mengetahui tentang sesuatu lebih jauh (Barat \& Selatan, n.d.). Berdasarkan pendapat diatas, dapat dikatakan bahwa berpikir kreatif merupakan aktivitas mental yang dilakukan seseorang dalam menghasilkan ide-ide baru secara terus-menerus dan mampu menyelesaikan suatu permasalahan dengan berbagai alternatif penyelesaian kemudian menguji kembali alternatif-alternatif penyelesaian masalah tersebut. Dengan kata lain berpikir merupakan aktivitas yang dilakukan ketika menghadapi sebuah objek. Dalam hal tersebut dibutuhkan kemampuan berpikir kreatif. Mengacu dari beberapa pendapat ahli maka dapat disimpulkan bahwa kreativitas kemampuan seseorang yang memiliki kriteria kelancaran (fluency), keluwesan (flexibility), dan memperinci (elaboration).

Model pembelajaran Challenge Based Learning merupakan pembelajaran baru yang menggabungkan pembelajaran berbasis masalah, pembelajaran berbasis proyek, dan pembelajaran konstekstual yang difokuskan pada penyelesaian dari permasalahan yang ada di kehidupan sehari-hari. Pembelajaran ini menciptakan ruang dimana peserta didik berpikir kritis dan aktif mencari solusi untuk memecahkan tantangan yang ada. Modul pembelajaran Challenge Based Learning adalah modul yang bercirikan sintaks dari pembelajaran Challenge Based Learning yang meliputi pemberian big idea atau gagasan utama, essential question atau pemberian pertanyaan penting, challenge atau tantangan, guiding question atau pertanyaan pemandu, guiding activity atau aktivitas pemandu, solution atau solusi, kemudian publikasi (Modul et al., 2015). Dengan model pembelajaran Challenge Based Learning ini diharapkan mampu mengembangkan kemampuan berpikir kreatif merupakan salah satu dari berpikir tingkat tinggi. Challenge Based Learning menggunakan masalah dalam kehidupan nyata sebagai tantangan dimana siswa dapat mengaplikasikan pengetahuan dan keterampilannya dalam memecahkan tantangan tersebut. Berdasarkan pendapat para ahli, maka dapat disimpulkan bahwa Challenge Based Learnig adalah pembelajaran masalah yang dimulai dari kehidupan sehari-hari yang nantinya menjadi tantangan bagi siswa untuk menyelesaikannya. Challenge Based Learning merupakan suatu pembelajaran yang menggabungkan pembelajaran berbasis masalah, pembelajaran berbasis proyek, dan pembelajaran kontekstual. Ketika dihadapkan dengan tantangan seseorang dan kelompoknya akan sukses memanfaatkan pengalaman, memanfaatkan sumber daya internal dan eksternal, mengembangkan rencana dan mendorong untuk menemukan solusi terbaik. Challenge Based Learning adalah kerangka kerja yang fleksibel, dengan setiap implementasi, kerangka kerja yang ditinjau ulang. Pembelajaran berbasis tantangan dirancang agar fleksibel, mudah disesuaikan. Pendekatan ini dapat memperluas praktik saat ini, berfungsi sebagai kerangka untuk peristiwa tertentu selama tahun ajaran, dan bertindak sebagai kerangka menyeluruh untuk perencanaan strategis, pengambilan keputusan, dan pembelajaran (Nichols et al., 2016). Challenge Based Learning juga menjadi salah satu ide yang digunakan dalam pembelajaran, dengan hasil yang bisa ditiru dan terukur untuk siswa hampir setiap tingkat kelas. Tidak jauh berbeda dengan model pembelajaran lain, tentunya model Challenge Based Learning juga memiliki kelebihan dan kelemahan. Adapun kelebihan model Challenge Based Learning memiliki relevansi permasalahan yang diberikan dengan kehidupan nyata dan berfokus pada permasalahan yang diberikan, proses pengambilan keputusan atau solusi, dan integrasi dengan teknologi. Untuk pelaksanaannya model Challenge Based Learning juga dilaksanakan di luar kelas atau lingkungan sekitar siswa. Siswa secara langsung melakukan kegiatan observasi di lingkungan sekitar tempat tinggalnya untuk mengamati keadaan lingkungan sekitar dan menggali informasi yang dibutuhkan. Selama pengamatan siswa juga dituntut untuk berinteraksi langsung dengan masyarakat sehingga 
informasi yang didapatkan tidak hanya berasal dari buku atau sumber internet. Selama pengamatan siswa juga dituntut untuk berinteraksi langsung dengan masyarakat. Pemanfaatan lingkungan sebagai sarana belajar tersebut memberi peluang siswa mendapat informasi secara langsung (Mukarromah et al., 2020).

Model pembelajaran Challenge Based Learning dapat mendorong siswa untuk merancang, meneliti, dan mendiagnosis suatu permasalahan. Pengetahuan yang diperoleh di sekolah jika diterapkan pada kehidupan nyata untuk memecahkan permasalahan akan dapat meningkatkan kemampuan siswa dalam menyelesaikan permasalahan. Proses pembelajaran yang menekankan pada pengambilan keputusan pemecahan masalah didasarkan pada informasi yang dapat meningkatkan kemampuan berpikir kritis siswa. Tahapan-tahapan model Challenges Based Learning (CBL), meliputi ide besar, pertanyaan penting, tantangan, pertanyaan pemandu, kegiatan pemandu, sumber pemandu, solusi, penilaian dan publikasi. Pada tahapan-tahapan tersebut siswa dilibatkan berinteraksi secara aktif untuk menemukan, menyelidiki, dan menyelesaikan tantangan yang diberikan oleh pendidik. Tantangan peserta didik berkaitan dengan masalah kehidupan nyata yang didesain secara menarik untuk kegiatan pembelajaran. Tantangan yang menarik diharapkan dapat merangsang motivasi ekstrinsik peserta didik untuk belajar dengan sungguh-sungguh. Tantangan yang diberikan diharapkan dapat menuntut siswa agar mandiri, kreatif, dan inovatif dalam kegiatan penyelidikan, siswa menemukan tantangannya sendiri, melakukan kegiatan penyelidikan, serta memberikan solusi terhadap tantangan tersebut (Juniarso, 2020). Menghadapi realita seperti yang diuraikan, maka dalam pembelajaran matematika diperlukan suatu model pembelajaran yang dapat memfasilitasi siswa dalam meningkatkan dan melatih kemampuan berpikir kreatif matematis siswa. Model pembelajaran yang dapat membantu siswa dalam menyelesaikan soalsoal matematika non rutin. Salah satu model pembelajaran yang dapat melatih dan mengembangkan kemampuan berpikir kreatif matematis siswa adalah model pembelajaran Challenge Based Learning. Model pembelajaran Challenge Based Learning merupakan pembelajaran baru yang menggabungkan pembelajaran berbasis masalah, pembelajaran berbasis proyek, dan pembelajaran konstekstual yang difokuskan pada penyelesaian dari permasalahan yang ada di kehidupan sehari-hari. Pembelajaran ini menciptakan ruang dimana peserta didik berpikir kritis dan aktif mencari solusi untuk memecahkan tantangan yang ada. Model pembelajaran Challenge Based Learning adalah model yang bercirikan sintaks dari pembelajaran Challenge Based Learning yang meliputi engage, investigate, dan act. Dengan model pembelajaran Challenge Based Learning ini diharapkan mampu mengembangkan kemampuan berpikir kreatif matematis siswa.

\section{METODE PENELITIAN}

Metode penelitian yang digunakan dalam penelitian ini adalah kuasi eksperimen. Sedangkan, desain penelitian yang digunakan adalah Randomized Control Group Post Test Only. Penelitian ini dilaksanakan di SMP Negeri 169 Jakarta kelas VII. Waktu penelitian dilaksanakan di semester ganjil tahun ajaran 2018/2019 yaitu pada bulan Desember 2018. Hasil pengujian reliabitas menunjukkan koefisien reliabilitas sebesar 0,880 dan termasuk kategori tinggi. Hasil perhitungan uji taraf kesukaran butir adalah terdapat 3 soal dengan kriteria mudah, 2 soal kriteria sedang, dan 1 soal kriteria sulit. Teknik pengumpulan data yang dilakukan yaitu berupa tes kemampuan berpikir kreatif matematis yang memuat tiga indikator yaitu fluency, flexibility, dan elaboration pada materi persamaan linear satu variabel. Kemudian tes diberikan kepada kedua kelompok siswa eksperimen dan kontrol setelah dilakukan pembelajaran.

Populasi dalam penelitian ini adalah seluruh siswa kelas VII di SMP Negeri 169 Jakarta. Sampel penelitian ini berasal dari populasi terjangkau yang dilakukan dengan cara pengambilan sampel dari seluruh kelas VII dengan teknik cluster random sampling. Sampel akan dipilih dari dua kelas secara acak yang akan menjadi kelompok eksperimen dan kelompok kontrol. Kelompok ekperimen adalah kelas dengan perlakuan pembelajaran Challenge Based Learning. Kemudian kelompok kontrol adalah kelas dengan perlakuan pembelajaran konvensional. 
Data yang diperoleh dari hasil tes kedua kelompok sampel dengan pemberian tes yang dilakukan pada akhir pokok pembahasan materi yang telah dipelajari dan disusun berdasarkan silabus. Adapun hal-hal yang harus diperhatikan dalam pengumpulan data tersebut sebagai berikut:

a. Variabel dalam penelitian ini adalah model Challenge Based Learning sebagai variabel independen. Kemampuan berpikir kreatif matematis siswa sebagai variabel dependen.

b. Sumber data dalam penelitian ini adalah siswa yang menjadi sampel penelitian dan guru mata pelajaran matematika.

c. Instrumen yang digunakan dalam penelitian ini berupa tes kemampuan berpikir kreatif matematis. Soal tes untuk mengukur tingkat kemampuan berpikir kreatif matematis siswa yang disusun dalam bentuk uraian (essay).

Penelitian ini menggunakan penelitian kuantitatif, yaitu dengan menggunakan perhitungan yang sistematis karena berhubungan dengan nilai berupa angka atau hasil. Data tersebut kemudian diolah untuk mengetahui apakah ada pengaruh penerapan pembelajaran Challenge Based Learning terhadap kemampuan berpikir kreatif matematis siswa.

\section{HASIL DAN PEMBAHASAN PENELITIAN}

Penelitian dilakukan sebanyak 5 pertemuan dan pada pertemuan kelima kelas yang dijadikan sebagai sampel penelitian diberikan untuk mengukur kemampuan berpikir kreatif matematis (KBKM) peserta didik. Hasil penelitian tentang kemampuan kreatif kelas eksperimen dan kelas kontrol disajikan dalam Gambar 1. Secara lebih jelas pembahasan mengenai penyebab perbedaan persentase nilai rata-rata tes kemampuan berpikir kreatif kelas eksperimen dan kelas kontrol berdasarkan indikator akan dibahas pada bagian Pembahasan Hasil Penelitian. Secara visual, perbandingan persentase nilai rata-rata kemampuan berpikir kreatif siswa kelas eksperimen dan kelas kontrol disajikan dalam diagram batang seperti pada gambar berikut:

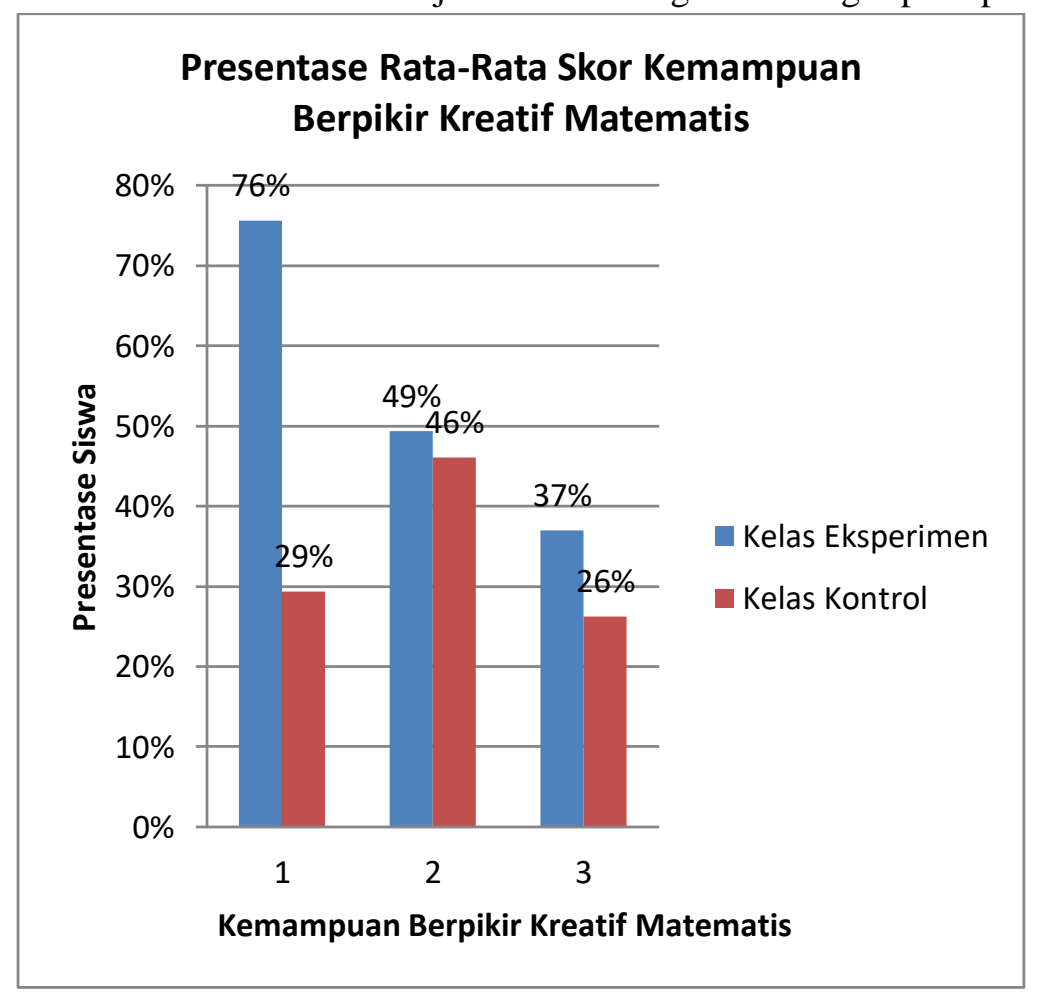

Gambar 1. Diagram Batang Persentase Kemampuan Berpikir Kreatif Siswa Berdasarkan Indikator 
Dari Gambar 1. terlihat bahwa persentase rata-rata skor kemampuan berpikir kreatif kelas eksperimen memperoleh hasil yang lebih tinggi dibandingkan dengan skor kemampuan berpikir kreatif kelas kontrol. Hasil uji normalitas data dengan uji Shapiro-wilk menggunakan perangkat lunak SPSS diperoleh hasil kelas eksperimen dengan sig. $=0,272>\alpha=0,05$ dan kelas kontrol dengan sig. $=0,127>\alpha=0,05$ yang artinya kedua kelas tersebut berasal dari populasi yang berdistribusi normal. Selanjutnya hasil uji homogenitas dengan uji Levene's diperoleh hasil nilai sig. Sebesar $0,623>\alpha=0,05$. Jika kedua data berdistribusi normal dan homogen, maka pengujian dilanjutkan dengan uji hipotesis. Uji hipotesis dilakukan untuk mengetahui apakah kemampuan berpikir kreatif matematis kelas eksperimen yang diajarkan menggunakan model pembelajaran Challenge Based Learning lebih tinggi dari kemampuan bepikir kreatif matematis kelas kontrol yang diajarkan menggunakan model pembelajaran ekspositori. Uji hipotesis yang digunakan dalam penelitian menggunakan analisis independent sample T test yang terdapat pada perangkat lunak SPSS. Hasil perhitungan uji hipotesis yang digunakan dalam penelitian disajikan pada Tabel 1. berikut :

Tabel 1. Hasil Uji Hipotesis Tes Kemampuan Berpikir Kreatif Matematis Siswa Kelas Eksperimen dan Kelas Kontrol

Independent Samples Test

\begin{tabular}{|c|c|c|c|c|c|c|c|c|c|c|}
\hline & & $\begin{array}{r}\text { Leve } \\
\text { Test } \\
\text { Equal } \\
\text { Varia }\end{array}$ & $\begin{array}{l}\text { ne's } \\
\text { for } \\
\text { ity of } \\
\text { nces }\end{array}$ & & & & st for Equali & ty of Means & & \\
\hline & & & & & & & & & $\begin{array}{r}95 \% \text { Co } \\
\text { Interva } \\
\text { Diffe }\end{array}$ & $\begin{array}{l}\text { fidence } \\
\text { of the } \\
\text { ence }\end{array}$ \\
\hline & & $\mathbf{F}$ & Sig. & t & df & $\begin{array}{l}\text { Sig. (2- } \\
\text { tailed) }\end{array}$ & $\begin{array}{c}\text { Mean } \\
\text { Difference }\end{array}$ & $\begin{array}{l}\text { Std. Error } \\
\text { Difference }\end{array}$ & Lower & Upper \\
\hline Nilai & $\begin{array}{l}\text { Equal } \\
\text { variances } \\
\text { assumed }\end{array}$ & ,244 & ,623 & $\begin{array}{r}3,28 \\
8\end{array}$ & 68 & ,002 & 1,800 & ,547 & ,708 & 2,892 \\
\hline & $\begin{array}{l}\text { Equal } \\
\text { variances } \\
\text { not } \\
\text { assumed }\end{array}$ & & & $\begin{array}{r}3,28 \\
8\end{array}$ & $\begin{array}{r}7,71 \\
3\end{array}$ & ,002 & 1,800 & ,547 & ,708 & 2,892 \\
\hline
\end{tabular}

Dari Tabel 1. terlihat bahwa hasil uji kesamaan dua rata-rata kelas eksperimen dan kelas kontrol menunjukkan nilai $\mathrm{t}=3,288$ dengan $\mathrm{df}=68$ dan $p$-value $=$ sig. $(2$-tailed $)=0,002<0,05$. Hal ini menunjukkan penolakan $\mathrm{H}_{0}$ dan penerimaan $\mathrm{H}_{1}$, yang artinya rata-rata kemampuan berpikir kreatif matematis siswa kelas eksperimen dalam model pembelajaran Challenge Based Learning lebih tinggi daripada rata-rata kemampuan berpikir kreatif matematis siswa kelas kontrol yang diajarkan dengan pembelajaran konvensional. Dapat dikatakan bahwa model pembelajaran Challenge Based Learning berpengaruh positif terhadap kemampuan berpikir kreatif matematis siswa.

Model pembelajaran Challenge Based Learning dideskripsikan sebagai bentuk khusus dari pembelajaran berbasis masalah, dimana permasalahannya realistik dan alamiah. Dalam proses pembelajaran, guru menghadirkan ide besar yang dapat mengakomodasi keseluruhan proses pembelajaran yang akan dilaksanakan. Dari ide besar yang disajikan akan muncul pertanyaan-pertanyaan esensial dan tantangan dari guru yang harus diselesaikan oleh siswa. Proses pembelajaran tersebut akan menjadi aktivitas pemandu siswa dalam menyelesaikan tantangan, selain dibantu dengan pertanyaan dan sumber-sumber pemandu. Hasil akhir dari proses pembelajaran adalah adanya konsep yang dipelajari siswa untuk menciptakan solusi terhadap tantangan yang dihadirkan. 
Pembelajaran dengan model pembelajaran Challenge Based Learning ini membuat siswa menjadi lebih aktif dalam memunculkan pertanyaan dan memberikan gagasan-gagasan kreatif dari masalah-masalah yang diberikan, siswa juga terbiasa untuk mengidentifikasi setiap tantangan untuk kemudian mengambil kesimpulan. Pada model pembelajaran Challenge Based Learning dibagi menjadi tiga tahapan yaitu engage, investigate dan act dengan menggunakan lembar test. Pada kegiatan engage, siswa akan mengumpulkan berbagai informasi untuk menyelesaikan sebuah masalah. Pada kegiatan kedua adalah investigate, siswa menyelesaikan beberapa masalah berdasarkan tahapan Challenge Based Learning. Kegiatan yang ketiga adalah act yang meliputi kegiatan diskusi dan siswa mengumpulkan berbagai pendapat dari siswa lainnya yang berada dalam satu kelompok mengenai penyelesaian dari tahap sebelumnya. Kemudian, setelah selesai semua kelompok menyampaikan penyelesaian kepada siswa lain di depan kelas.

Pada kelas kontrol menggunakan pembelajaran konvensional dengan pendekatan saintifik. Pendekatan saintifik (Saintific Approach) terbagi menjadi 5 tahapan yang terdiri dari mengamati, menanya, mengumpulkan informasi, mengasosiasi, dan mengkomunikasi. Tahapan tersebut berkaitan dengan tahapan pada model pembelajaran Challenge Based Learning, yaitu mengamati seperti engage pada model pembelajaran Challenge Based Learning, menanya dan mengumpulkan informasi seperti investigate pada model pembelajaran Challenge Based Learning, mengasosiasi dan mengkomunikasi seperti act pada model pembelajaran Challenge Based Learning. Pada akhir pembelajaran guru memberikan latihan soal yang akan diselesaikan oleh masing-masing siswa. Perbedaan kemampuan berpikir kreatif matematis siswa dalam penelitian ini disebabkan oleh perbedaan perlakuan (treatment) yang dilakukan kepada dua kelompok sampel. Dalam hal ini, terdapat kesamaan pada kelas eksperimen dan kelas kontrol yaitu kedua kelas diberi lembar test namun dengan tingkat kesulitan soal yang berbeda. Pemaparan lebih jelas perbedaan pada kelas eksperimen dan kelas kontrol akan dijabarkan melalui hasil lembar test sebagai berikut :

\section{Proses Pembelajaran Pada Kelas Eksperimen}

Tahap Engage .Pada tahap ini siswa dilibatkan pada ide besar (big idea) yang akan dijadikan topik permasalahan dan memberikan pertanyaan penting (essential question) beserta tantangan (challenge) yang berkaitan dengan ide besar tersebut dan harus dipecahkan oleh siswa secara berkelompok, sebelum melakukan penyelidikan pada tahap selanjutnya. Pada pertemuan pertama, siswa masih memiliki kesulitan untuk menerapkan pembelajaran Challenge Based Learning. Namun pada saat pertemuan kedua, siswa sudah mulai memahami perintah sesuai lembar kerja. Berikut contoh jawaban siswa pada tahap engage:

Tahap Investigate, Setelah siswa mendapatkan berbagai informasi dari tahap sebelumnya, maka siswa dapat mengerjakan beberapa soal yang berkaitan dengan masalah tersebut. Tahap kedua dalam model Challenge Based Learning yaitu Investigate. Pada tahap ini terdapat guiding questions yaitu pertanyaan pemandu yang dapat melatih siswa untuk aktif menganalisis setiap jawaban dari berbagai sumber.

Dalam lembar kerja pada tahapan Investigate diberikan masalah yang berkaitan dengan persamaan dan pertidaksamaan linear satu variabel. Pertanyaan-pertanyaan tersebut dibuat agar siswa terbiasa aktif menganalisis setiap pertanyaan yang diajukan. Pada masalah tersebut terlihat bahwa siswa dapat memberikan jawaban sesuai soal yang diminta. Jawaban setiap kelompok pun tidak jauh berbeda.

Tahap Act ,Tahap ini merupakan tahapan terakhir dari Challenge Based Learning. Pada tahap ini siswa sudah memiliki dasar pengetahuan yang kuat untuk mulai melaksanakan strategi yang telah ditetapkan karena telah melalui tahapan sebelumnya yaitu Investigate, sehingga siswa sudah memiliki konsep yang jelas dan digunakan untuk memecahkan tantangan untuk kemudian menarik kesimpulan.

Kemudian, beberapa kelompok mempresentasikan jawaban dan memberikan kesimpulan atas pembelajaran yang telah didapat siswa mengenai persamaan dan pertidaksamaan linear satu variabel berdasarkan hasil pengamatan yang telah didapat kepada teman-teman di depan kelas. Selanjutnya, satu orang mewakili satu kelompok mempresentasikan hasil diskusi mereka serta memberikan kesimpulan atas 
1950 Challenge Based Learning Dalam Meningkatkan Kemampuan Berpikir Kreatif Siswa Pada Materi Persamaan Linear Satu Variabel - Fairazatunnisa, Gelar Dwirahayu, Eva Musyrifah

DOI: https://doi.org/10.31004/edukatif.v3i5.702

pembelajaran siswa dari tahap awal hingga akhir. Pada tahapan ini guru membantu siswa untuk memfasilitasi jalannya presentasi. Kemudian masing-masing kelompok mempresentasikan jawaban mengenai persamaan linear satu variabel beserta rumus yang telah diperoleh.

\section{Proses Pembelajaran Pada Kelas Kontrol}

Tahap Mengamati, Pada tahap ini guru memberikan penjelasan materi dengan metode ceramah mengenai persamaan dan pertidaksamaan linier satu variabel, kemudian siswa mengamati penjelasan yang guru berikan dan mengumpulkan informasi-informasi dari sebuah masalah secara berkelompok. Informasi ini akan berguna untuk menyelesaikan masalah-masalah pada tahap selanjutnya.

Tahap Menanya, Setelah siswa mendapatkan berbagai informasi dari tahap mengamati, maka siswa dapat mengerjakan beberapa soal yang berkaitan dengan masalah tersebut. Siswa diberi kesempatan untuk mengajukan pertanyaan tentang informasi yang kurang dipahami dari pengamatan yang dilakukan sebelumnya atau pertanyaan untuk mendapatkan informasi tambahan. Pada tahap ini siswa mulai diberi beberapa masalah namun berbeda dengan kelas eksperimen, masalah pada kelas kontrol memiliki tingkatan kesulitan yang lebih rendah dibandingkan dengan kelas eksperimen.

Tahap Mengumpulkan Informasi/ Mencoba, Dalam tahap ini, siswa mencoba berbagai cara yang tepat untuk menyelesaikan masalah. Dengan adanya percobaan, siswa dapat menyimpulkan mana solusi yang tepat dalam menyelesaikan masalah. Selama proses ini guru ikut membimbing dan mengamati proses percobaan.,Pada tahap ini siswa membuat sebuah cerita atau narasi yang memiliki unsur-unsur berupa kalimat terbuka dan kalimat tertutup.

Tahap Mengasosiasi, Setelah siswa melakukan tahap mengumpulkan informasi, siswa diharapkan dapat menyelesaikan beberapa pertanyaan pada lembar kerja. Pada tahap ini, masing-masing kelompok akan memberikan penyelesaian dari pengetahuan yang telah didapat pada tahap mengumpulkan informasi/ mencoba. Hal ini dapat melatih siswa untuk aktif menganalisis setiap jawaban dari berbagai sumber, sehingga siswa pada kelompok eksperimen lebih terbiasa dalam memberikan alasan pada tiap jawaban yang diberikan. Berikut adalah jawaban siswa pada lembar kerja.

Tahap Mengkomunikasi

Pada tahap akhir pembelajaran, siswa menyimpulkan hasil pengamatan dengan mengkomunikasikannya di dalam kelas. Dalam tahap ini melatih siswa untuk lebih berani dalam berbicara di depan kelas dan mengeluarkan pendapatnya. Kemudian guru membantu siswa untuk memfasilitasi jalannya presentasi. Kemudian masing-masing kelompok mempresentasikan jawaban mengenai kalimat terbuka dan kalimat tertutup telah diperoleh.

Hasil penelitian menunjukkan bahwa terdapat perbedaan rata-rata kemampuan berpikir kreatif matematis siswa kelas eksperimen dan kelas control, karena adanya perbedaan perlakuan pada kedua kelas tersebut. Hasil uji hipotesis penelitian menunjukkan bahwa kemampuan berpikir kreatif matematis yang diajarkan dengan model pembelajaran Challenge Based Learning lebih tinggi dibandingkan siswa yang diajarkan menggunakan pembelajaran konvensional. Hal ini menunjukkan bahwa model pembelajaran Challenge Based Learning berpengaruh dalam meningkatkan kemampuan berpikir kreatif matematis siswa.

Mengacu pada teori Mark Nichols yang menyatakan bahwa pembelajaran dengan model Challenge Based Learning menjadikan siswa lebih aktif dalam memunculkan pertanyaan dan memberikan gagasangagasan kreatif dari masalah yang diberikan, siswa juga terbiasa untuk mengidentifikasi setiap tantangan. Hasil penelitian ini juga sejalan dengan penelitian yang dilakukan oleh Hanna Ramadhana yang menunjukkan bahwa model pembelajaran Challenge Based Learning dengan setting kooperatif lebih efektif dibandingakan dengan model konvensional. Penelitian ini serupa juga dengan penelitian yang dilakukan oleh Ana Matofani yang menunjukkan bahwa Interlocked Problem Posing dengan setting kooperatif lebih efektif dalam mempengaruhi kemampuan berpikir kreatif matematis dibandingkan dengan strategi ekspositori. Berikut akan 
1951 Challenge Based Learning Dalam Meningkatkan Kemampuan Berpikir Kreatif Siswa Pada Materi Persamaan Linear Satu Variabel - Fairazatunnisa, Gelar Dwirahayu, Eva Musyrifah

DOI: https://doi.org/10.31004/edukatif.v3i5.702

dibahas hal-hal yang menyebabkan nilai rata-rata kelas eksperimen lebih tinggi dibandingkan dengan kelas kontrol berdasarkan indikatornya. Selain itu, juga akan dibahas mengenai proses pembelajaran pada kelas eksperimen serta kelas kontrol yang turut membedakan nilai rata-rata kedua kelompok tersebut.

Pengujian hipotesis yang telah dilakukan menghasilkan kesimpulan bahwa kemampuan berpikir kreatif siswa kelas eksperimen yang diajarkan menggunakan model pembelajaran Challenge Based Learning lebih tinggi daripada kemampuan berpikir kreatif matematis siswa pada kelas kontrol yang diajarkan dengan pembelajaran ekspositori. Kemampuan berpikir kreatif matematis kelas eksperimen tidak terlepas dari model pembelajaran yang diterapkan yaitu model Challenge Based Learning. Model Challenge Based Learning terdiri dari 3 tahapan yaitu tahap engage, invastigate, dan act. Berikut adalah hasil test yang telah dilakukan oleh siswa dengan model pembelajaran Challenge Based Learning.

Indikator elaboration yang diukur pada penelitian ini adalah kemampuan siswa untuk merinci dan mengembangkan gagasan atau penyelesaian masalah. Dalam soal elaboration yang diberikan, siswa diharapkan mampu memberikan arti yang lebih mendalam terhadap sebuah jawaban dari sebuah masalah. Soal yang diberikan adalah nomor 1 dan 2 yang mewakili indikator elaboration. Berikut disajikan contoh soal nomor 1 yang merupakan soal KBKM indikator elaboration. Risa, Meli, dan Sasa membagi tugas mengantar undangan ke 105 orang. Meli mengantar 10 amplop undangan lebih banyak dari Risa. Sasa mengantar 5 amplop undangan lebih sedikit dari 2 kali yang diantar Risa. Jika undangan yang diantar Risa sebanyak $\mathrm{x}$ amplop. Uraikan secara rinci bagaimana kamu dapat menentukan banyaknya undangan yang diantar Meli dan Sasa?

Dalam soal elaboration tersebut, siswa diharapkan untuk merinci dan mengembangkan gagasan atau penyelesaian dari masalah diatas. Berikut ini disajikan contoh jawaban dari siswa kelas eksperimen dengan model pembelajaran Challenge Based Learning dan kelas kontrol dengan pembelajaran ekspositori. Berikut ini akan disajikan contoh jawaban yang diberikan siswa kelas eksperimen dan kelas kontrol.

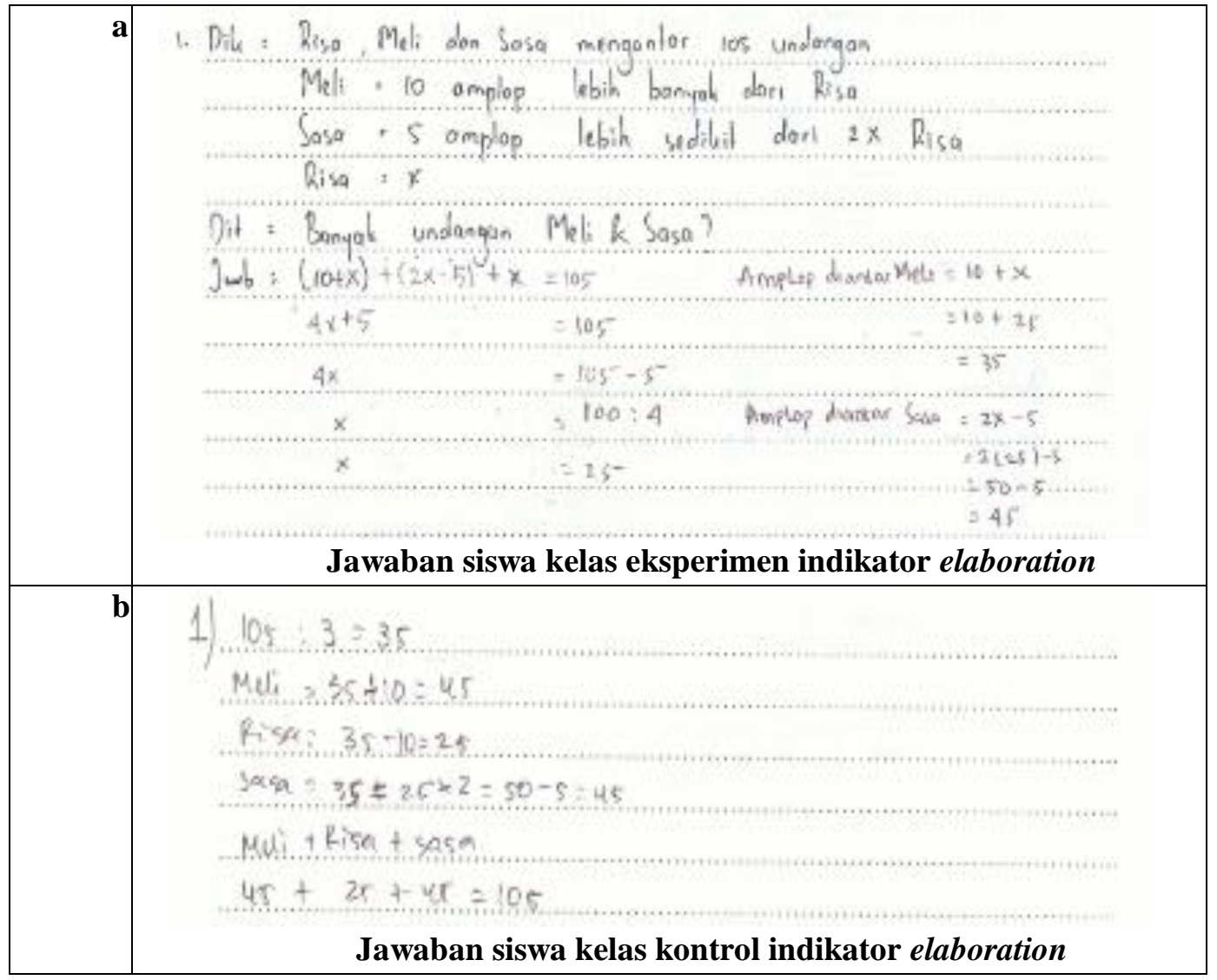

Gambar 2. Jawaban Siswa Kelas Eksperimen (a) dan Kelas Kontrol (b) Pada Indikator Elaboration 
Dari Gambar 2. terlihat jawaban siswa kelas eksperimen (a) dan kelas kontrol (b) kedua kelas tersebut sudah mampu merinci soal dengan mengembangankan jawaban, namun yang membedakan adalah pada kelas eksperimen jawaban siswa lebih tepat didasarkan pada cara siswa mengembangkan rincian informasi yang terdapat di dalam soal dengan tepat. Sedangkan pada kelas kontrol jawaban siswa kurang tepat didasarkan pada cara siswa menjawab tidak disertai dengan rincian informasi yang ada pada soal. Hal ini dikarenakan pada kelas eksperimen menggunakan pembelajaran Challenge Based Learning, sedangkan kelas kontrol hanya mendapatkan pembelajaran konvensional. Pembelajaran Challenge Based Learning terdapat tahapan investigate dan act. Pada tahapan investigate siswa dilatih untuk menganalisis setiap pertanyaan yang telah diberikan, dan pada tahapan act siswa dilatih menyimpulkan hasil jawaban dengan menyesuaikan pertanyaan yang diberikan, sehingga siswa terbiasa merinci dan mengembangkan gagasan atau elaboration.

Indikator fluency yang diukur pada penelitian ini adalah kemampuan siswa untuk menghasilkan banyak jawaban. Dalam soal fluency yang diberikan, siswa diharapkan mampu memberikan banyak gagasan, jawaban ataupun penyelesaian masalah serta dapat dengan cepat melihat sebuah kekurangan atau kesalahan pada suatu objek. Soal yang diberikan adalah nomor $3 \mathrm{a}$ dan $4 \mathrm{~b}$ yang mewakili indikator fluency. Berikut disajikan contoh soal nomor 4b yang merupakan soal KBKM indikator fluency. 4b) Untuk melakukan perjalanan Eka dari kota A ke kota D, kita harus menaiki bus. Ongkos bus dari kota A ke B Rp 3.000,00, kemudian dari kota A ke C adalah Rp 2.000,00 lebih dari 2 kali lipat jarak kota A ke B. Lalu ongkos bus dari kota B ke C adalah Rp 1.000,00 lebih dari jarak kota A ke B. Ongkos bus dari kota B ke D adalah 3 kali lipat dari A ke B dan ongkos bus dari kota $\mathrm{C}$ ke D adalah 2 kali lipat dari jarak A ke B.

b. Gambarkan dua jalur bus yang dapat dilalui oleh Eka.

Pada soal tersebut siswa diharapkan mampu memberikan penafsiran soal dan memikirkan memberikan banyak cara dalam menjawab soal tersebut. Berikut disajikan contoh jawaban yang diberikan siswa.

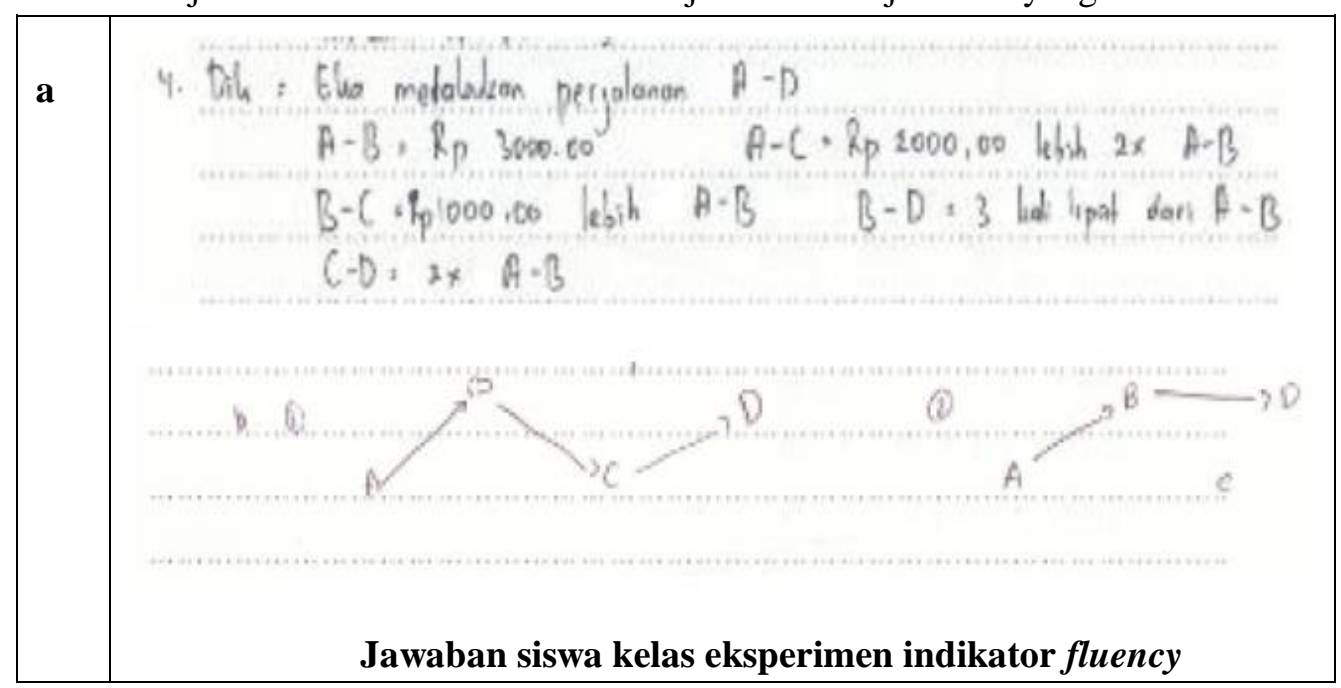




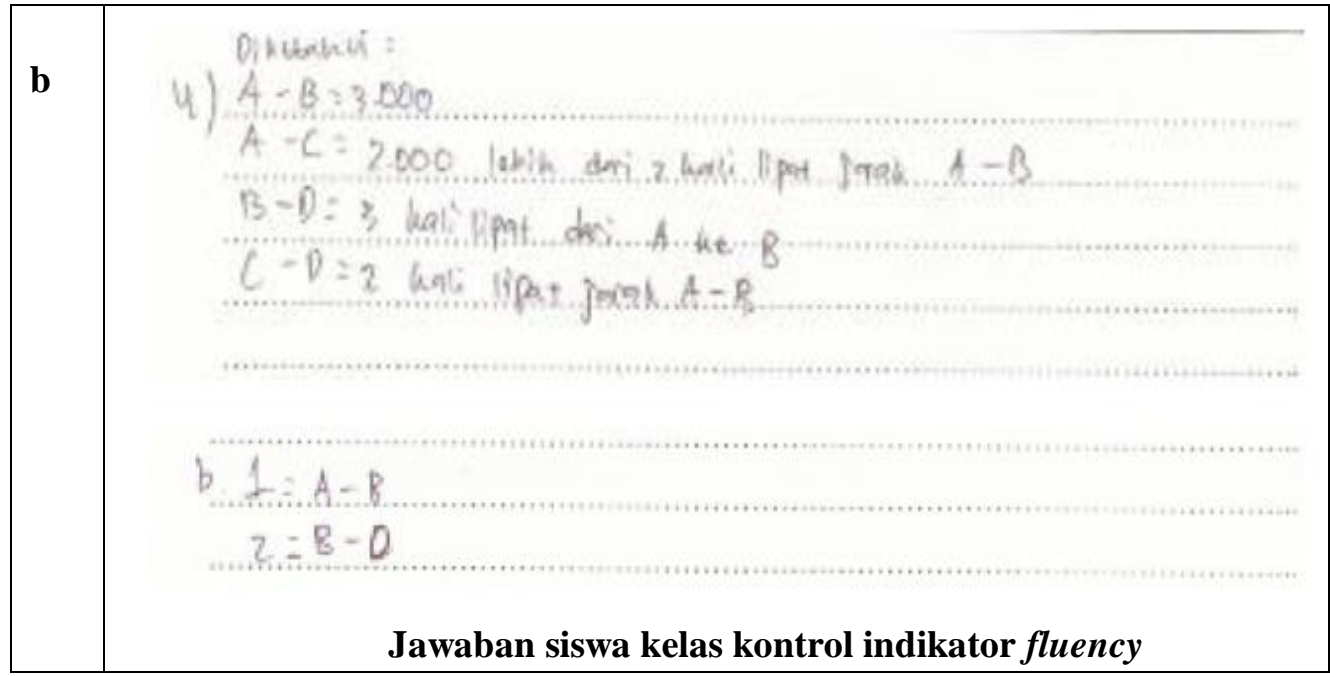

\section{Gambar 3. Jawaban Siswa Kelas Eksperimen (a) dan Kelas Kontrol (b) Pada Indikator Fluency}

Dari Gambar 3. terlihat jawaban siswa kelas eksperimen (a) dan kelas kontrol (b) pada kelas eksperimen siswa sudah mampu memberikan banyak cara yang berbeda dalam menjawab dengan memberikan gambaran yang tepat, sedangkan siswa kelas kontrol hanya memberikan jawaban yang sangat singkat dan tidak tepat. Hal ini dikarenakan pada kelas eksperimen menggunakan pembelajaran Challenge Based Learning, sedangkan kelas kontrol hanya mendapatkan pembelajaran konvensional. Pembelajaran Challenge Based Learning terdapat tahapan engage siswa dilatih untuk memecahkan ide besar yang menjadi topik permasalahan dan tantangan yang ada, sehingga siswa mampu memberikan banyak cara yang berbeda dalam menjawab atau fluency.

Indikator flexibility yang diukur pada penelitian ini adalah kemampuan siswa untuk memberikan alternatif jawaban berdasarkan kondisi yang diberikan. Dalam soal flexibility yang diberikan, siswa diharapkan mampu memberikan jawaban yang berbeda-beda serta mampu mengubah arah berpikir secara spontan. Soal yang diberikan adalah nomor $3 b$ dan 4 a yang mewakili indikator flexibility. Berikut disajikan contoh soal 3b yang merupakan soal KBKM indikator flexibility. 3.b) Ibu mempunyai sebidang tanah berbentuk persegi panjang dengan ukuran panjang $20 \mathrm{~m}$ dan lebarnya $6 \mathrm{y}-1$ dengan luas $100 \mathrm{~m}^{2}$. Dsebelah barat tanah tersebut ada masjid, kemudian di sebelah timur ada sebuah jalan kecil, lalu di sebelah selatan ada jalan raya, dan di sebelah utara ada rumah tetangga. Jika ibu ingin menjual tanah seluas $20 \mathrm{y} \mathrm{m}^{2}$ :

b. Berapakah harga jual tanah tersebut?

Pada soal tersebut siswa diharapkan mampu memberikan penafsiran soal dan memberikan alternatif jawaban dalam menyelesaikan soal tersebut. Berikut disajikan contoh jawaban yang diberikan siswa. 
1954 Challenge Based Learning Dalam Meningkatkan Kemampuan Berpikir Kreatif Siswa Pada Materi Persamaan Linear Satu Variabel - Fairazatunnisa, Gelar Dwirahayu, Eva Musyrifah DOI: https://doi.org/10.31004/edukatif.v3i5.702

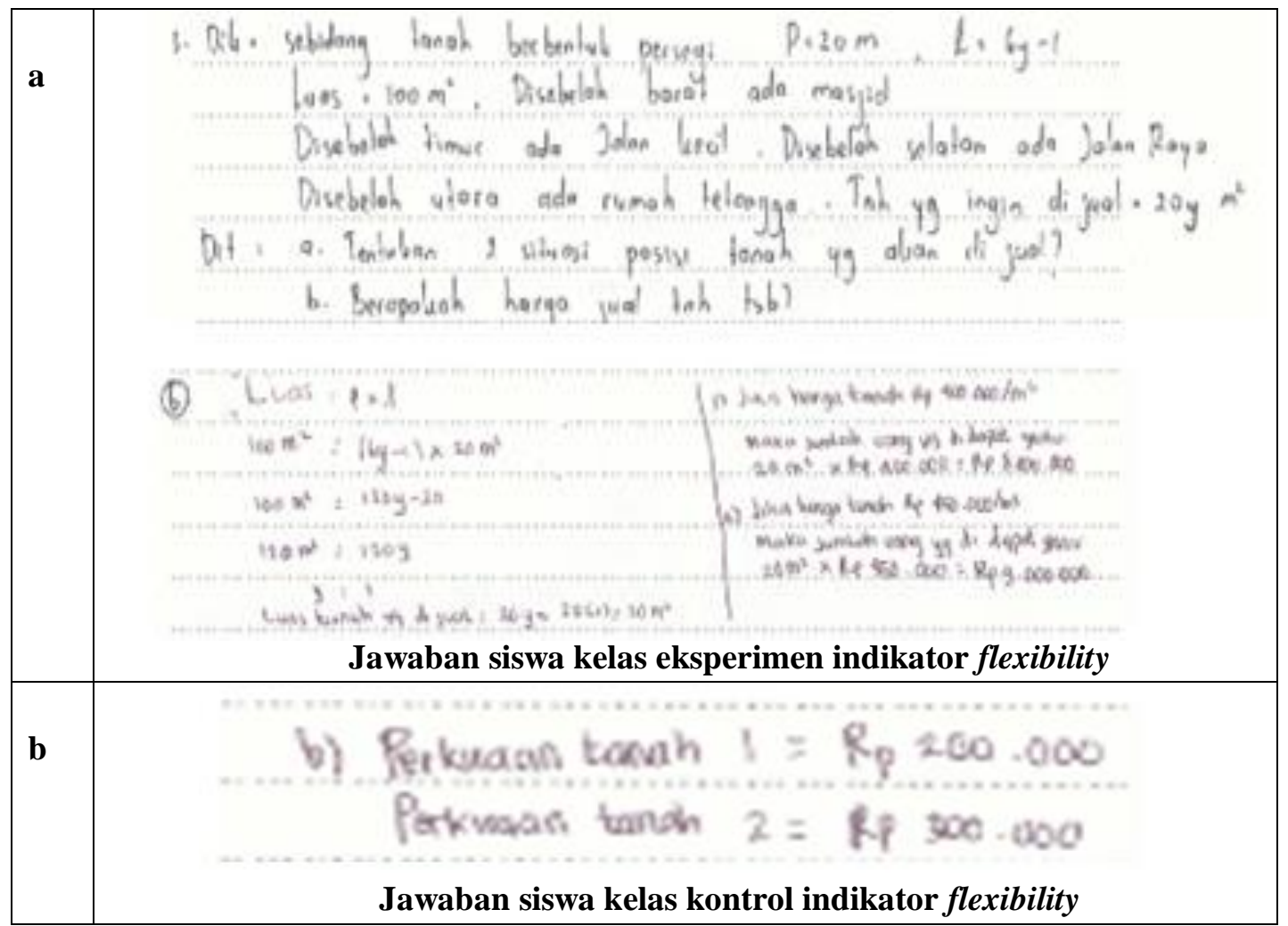

Gambar 4. Jawaban Siswa Kelas Eksperimen (a) dan Kelas Kontrol (b) Pada Indikator Flexibility

Dari Gambar 4. terlihat jawaban siswa kelas eksperimen (a) dan kelas kontrol (b) pada kelas eksperimen siswa sudah mampu memberikan jawaban yang bervariasi dengan mencari alternatif yang berbeda dengan menuliskan cara perhitungan yang lengkap, sedangkan pada kelas kontrol siswa menjawab dengan tidak menuliskan cara perhitugan yang mereka lakukan. Hal ini dikarenakan pada kelas eksperimen menggunakan pembelajaran Challenge Based Learning, sedangkan kelas kontrol hanya mendapatkan pembelajaran konvensional. Pembelajaran Challenge Based Learning terdapat tahapan engage dan act. Pada tahapan engage siswa dilatih memecahkan ide besar yang menjadi topik permasalahan dan tantangan yang diberikan, dan pada tahapan act yaitu siswa menyimpulkan hasil jawaban dengan menyesuaikan pertanyaan yang diberikan, sehingga siswa mampu memberikan jawaban yang bervariasi dengan mencari banyak alternatif yang berbeda-beda atau flexibility.

Pada kelas eksperimen, pembelajaran dengan model Challenge Based Learning di kelas menunjukkan bahwa siswa kesulitan pada tahap investigate sedangkan pada kelas kontrol, siswa merasa kesulitan pada tahap menalar dan menanya, karena dalam tahap tersebut siswa dituntut untuk aktif menyelidiki dan memperoleh hasil jawaban sendiri pada proses pembelajarannya Melalui model pembelajaran Challenge Based Learning, kemampuan penalaran kreatif dapat meningkat terutama dalam tahap engage, karena pada tahap ini dibutuhkan ide-ide kreatif yang muncul untuk dijadikan masalah. Tahap ini membangun kemampuan penalaran kreatif siswa, karena pertanyaan yang mereka ajukan, dibuat dengan mempertimbangkan berbagai sumber yang relevan terkait tantangan yang diberikan. Tahapan dalam proses pembelajaran dengan menggunakan Challenge Based Learning diharapkan mampu mengembangkan penalaran kreatif matematis siswa(Ilmiah et al., 2018).

Dalam pelaksanaan penelitian, peneliti mengalami beberapa keterbatasan terutama pada awal pertemuan pembelajaran. Berikut dipaparkan beberapa keterbatasan yang ditemukan dalam penelitian.

1. Penelitian dengan model pembelajaran Challenge Based Learning terdiri dari tahap engage, investigate dan act. Berdasarkan tahap tersebut, siswa masih merasa kesulitan pada tahap investigate, karena dalam tahap tersebut siswa dituntut untuk aktif menyelidiki pada proses pembelajarannya. 
1955 Challenge Based Learning Dalam Meningkatkan Kemampuan Berpikir Kreatif Siswa Pada Materi Persamaan Linear Satu Variabel - Fairazatunnisa, Gelar Dwirahayu, Eva Musyrifah DOI: https://doi.org/10.31004/edukatif.v3i5.702

2. Penelitian dengan kemampuan berpikir kreatif terdiri dari 3 indikator elaboration, fluency, dan flexibility. Hasil posttest menunjukkan bahwa tahap flexibility berada pada urutan terbawah dibandingkan dengan tahap elaboration dan tahap fluency. Sebab pada pengaplikasiannya, tahap flexibility lebih mengutamakan logika berfikir dan bernalar dalam menyelesaikan permasalahanya.

3. Penelitian ini hanya dilaksanakan pada pokok bahasan Persamaan dan Pertidaksamaan Linier Satu Variabel, sehingga penelitian ini belum dapat digeneralisasikan pada pokok bahasan yang lain yang memungkinkan siswa menggunakan model pembelajaran Challenge Based Learning pada proses pembelajarannya.

\section{KESIMPULAN}

Berdasarkan hasil analisis dan pembahasan dari penelitian yang telah dilakukan di SMP Negeri 169 Jakarta mengenai pengaruh pembelajaran Challenge Based Learning terhadap kemampuan berpikir kreatif matematis siswa. Dapat disimpulkan bahwa model pembelajaran Challenge Based Learning lebih tinggi daripada kelas yang diajar dengan model konvensional sehingga model Challenge Based Learning lebih efektif meningkatkan kemampuan berpikir kreatif matematis peserta didik dibanding model konvensional. Hasil penelitian diharapkan mampumemberikan perbaikan serta peningkatan kualitas pembelajaran di sekolah. Namun, disarankan untuk mempersiapkan desain model Challenge Based Learning dengan lebih baik sehingga pembelajaran lebih maksimal.

\section{DAFTAR PUSTAKA}

Barat, T., \& Selatan, J. (n.d.). Peran Berpikir Kreatif Dalam Proses. 2(3), 248-262.

Dwirahayu, G., Mas'Ud, A., Satriawati, G., Atiqoh, K. S. N., \& Dewi, S. (2021). Improving students' mathematical creative reasoning on polyhedron through concept-based inquiry model. Journal of Physics: Conference Series, 1836(1). https://doi.org/10.1088/1742-6596/1836/1/012073

Ilmiah, K., Seminar, P., Widuri, H. R., \& Dwirahayu, G. (2018). a 0.2 0.6. 1-2.

Juniarso, T. (2020). ModeKemampuan Berpikir Kreatif Mahasiswal Challenge Based Learning Terhadap. Jurnal Pendidikan - Teori, Penelitian, Dan Pengembangan, 5(1), 36-43.

Lince, R. (2016). Creative Thinking Ability to Increase Student Mathematical of Junior High School by Applying Models Numbered Heads Together. Journal of Education and Practice, 7(6), 206-212.

Meika, I., \& Sujana, A. (2017). Kemampuan Berpikir Kreatif Dan Pemecahan Masalah Matematis Siswa Sma. Jurnal Penelitian Dan Pembelajaran Matematika, $10(2), \quad 8-13$. https://doi.org/10.30870/jppm.v10i2.2025

Minarni, A., Napitupulu, E. E., \& Husein, R. (2016). Mathematical understanding and representation ability of public junior high school in North Sumatra. Journal on Mathematics Education, 7(1), 43-56. https://doi.org/10.22342/jme.7.1.2816.43-56

Modul, P., Challenge, B., Pada, L., Lingkungan, M., Berpikir, M. K., \& Siswa, K. (2015). Pengembangan Modul Berbasis Challenge Based.

Mukarromah, M., Budijanto, \& Utomo, D. H. (2020). Pengaruh Model Challenge Based Learning terhadap Kemampuan Berpikir Kritis Siswa SMA pada Materi Perubahan Iklim. Jurnal Pendidikan, 5(2), 214218.

Nichols, M., Cator, K., \& Torres, M. (2016). Challenge Based Learning Guide. Digital Promise and The Challenge Institute, November, 59. 
1956 Challenge Based Learning Dalam Meningkatkan Kemampuan Berpikir Kreatif Siswa Pada Materi Persamaan Linear Satu Variabel - Fairazatunnisa, Gelar Dwirahayu, Eva Musyrifah DOI: https://doi.org/10.31004/edukatif.v3i5.702

Nova, T., Yunianta, H., Rusilowati, A., Kristen, U., Wacana, S., \& Semarang, U. N. (2012). Kemampuan Berpikir Kreatif Siswa Pada Implementasi Project-Based Learning Dengan Peer and Self-Assessment Untuk Materi Segiempat Kelas Vii Smpn Rsbi 1 Juwana Di Kabupaten Pati. November, 978-979.

Nugrahaeni, A., Redhana, I. W., \& Kartawan, I. M. A. (2017). Penerapan Model Pembelajaran Discovery Learning Untuk Meningkatkan Kemampuan Berpikir Kritis Dan Hasil Belajar Kimia. Jurnal Pendidikan Kimia Indonesia, 1(1), 23. https://doi.org/10.23887/jpk.v1i1.12808

Purbaningrum, K. A. (2017). Kemampuan Berpikir Tingkat Tinggi Siswa Smp Dalam Pemecahan Masalah Matematika Ditinjau Dari Gaya Belajar. Jurnal Penelitian Dan Pembelajaran Matematika, 10(2), 40-49. https://doi.org/10.30870/jppm.v10i2.2029

Purwaningrum, J. P. (2016). Mengembangkan Kemampuan Berpikir Kreatif Matematis Melalui Discovery Learning Berbasis Scientific Approach. Refleksi Edukatika, 6(2), 145-157. https://doi.org/10.24176/re.v6i2.613 